\title{
The Romanian Orthodox Church and higher education: between academic freedom and constraint
}

\author{
Oliviu Felecan ${ }^{(10}$ 용 \\ Technical University of Cluj-Napoca, North University Centre of Baia Mare, Faculty of Letters, Str. Victoriei 76, \\ 430122 Baia Mare, Romania
}

\author{
Article info \\ History: \\ Accepted March 26, 2020 \\ Published June 10, 2020 \\ Key words: \\ theological education \\ university freedom \\ church \\ offensiphobia
}

Received February 10, 2020

\begin{abstract}
This study is likely to cause certain controversies, as it deals with problems of the way in which academic rights and freedom of expression are interpreted in the twenty-first century in a state of the European Union in which the Romanian Orthodox Church is trying to impose certain restrictions based on abuse of authority and dominant power. The continuous intrusion of the Romanian Orthodox Church in universities may be construed as a constant attack on university autonomy, as a wish to subordinate and control the academic milieu, under the pretext of managing theological matters. Theologians' scientific and teaching activity should depend on their merits exclusively, not on obtaining the consent of a bishop who, most often, does not pertain to the system of higher education.
\end{abstract}

\section{Preliminary remarks. The Orthodox Church and the Romanian society}

In Romanian society a specific phenomenon to a developing democracy is recorded: the position of certain institutions above the law, their derogation from legal provisions or influence on various decisions depending on the authority they have within the society, especially within the sphere of politics. A significant example in this respect is the Romanian Orthodox Church. Relying on the fact that Romania is one of the most religious countries in the world ${ }^{1}$ (Orthodox believers amount to 86.45 per cent of the population ${ }^{2}$ ), the Romanian Orthodox Church takes advantage of its dominant position and tries to establish a special "legal framework" to serve its interests and increase its privileges. A case in point is the fact that church income is not taxed, although the Romanian Orthodox Church has a considerable wealth consisting of places of worship (more than 18,000) and farming lands, forests, buildings (hotels) etc. [online].

The Romanian Orthodox Church has always known to negotiate its privileges and has successfully obtained everything it desired, as it has been, by definition, on the side of the political power ${ }^{3}$. The Church is considered the ideal electoral factor due to the influence it has on voters. Thus, no party has stood in its way ${ }^{4}$ and, in complicity, the Romanian Orthodox Church consolidated its superior position in democratic Romania.

The total control that the Romanian Orthodox Church wishes to have over the society and the ideas it promotes is also salient in education, in the implementation of religious education classes for thirteen

\footnotetext{
^Email address: olifelecan@yahoo.com.

${ }^{1}$ According to the Global Index of Religion and Atheism - 2012, compiled by Gallup International, Romania is the seventh state in the world and the first in the European Union with respect to religiousness, as 89 per cent of the population claims to be religious [online].

${ }^{2}$ The information is taken from the Romanian National Institute of Statistics, which published the results of the census conducted in 2011 [online].

${ }^{3}$ An objective analysis of the implication of the Romanian Orthodox Church in Romanian public life of the past decades is made by Schmitt (2018) in the Swiss newspaper Neue Zürcher Zeitung.

${ }^{4}$ Regardless of the parties/coalitions that followed in office, the Romanian Orthodox Church has always received considerable public funds (e.g., for the erection of churches and monasteries), whereas the country's infrastructure has been ignored.
} 
years in the system of secondary schooling. Religion is deliberately mistaken for religiousness, thereby allowing the Church to introduce teachers with theological training in all the schools in the country and giving the Church authority over schools and students implicitly. The pressure exerted on the curricula in the post-totalitarian age is actualised in certain provisions (protocols and acts) which are not legal in nature, but are followed by the heads of educational institutions in the systems of secondary and higher education alike. A recent study (see Felecan \& Munteanu Siserman, 2018, p. 173-184, originally Romanian) analyses how, by means of Protocolul cu privire la predarea disciplinei religie - cultul ortodox in invățămîntul preuniversitar și la organizarea învățămîntului teologic ortodox preuniversitar și universitar ('the Protocol regarding the teaching of religion - Orthodox faith in the system of secondary education and the organisation of Orthodox theological secondary and higher education', henceforth Protocol), signed in 2014 by the Ministry of National Education, the Romanian Patriarchate and the State Secretariat for Religious Denominations, "university autonomy is violated, authority is annulled in the case of ARACIS (the 'Romanian Agency for Quality Assurance in Higher Education's, the deciding factor for the establishment/termination of study programmes in Romanian higher education), decisions made by examination boards for obtaining academic positions are disregarded, restrictions are imposed on obtaining a promotion or the habilitation qualification, both of which should depend exclusively on candidates' scientific and teaching activity rather than on receiving the consent of a bishop who does not pertain to the university system". Although the protocol in question is not legally valid ${ }^{6}$ și are prevederi contrare cadrului legislativ românesc, este respectat în mai multe universităţi și produce efecte contrare spiritului academic european, dar și libertății universitare din România sau libertăţii de conștiință.

\section{Corpus}

This study analyses certain paragraphs of an official administrative document that is aimed at the educational system, in general, and university teaching staff with theological training, in particular. The document in question is a Decision of the Holy Synod ${ }^{7}$ of the Romanian Orthodox Church, adopted in the working session of 24 May 2018 (Argument no. 4761/2018). Two of the four paragraphs of the document read as follows:

1. The Holy Synod sanctions that Romanian Orthodox theologians must obtain the written consent of their Bishop and the blessing (approval) of the Patriarch of All Romania if they wish to become members of Orthodox, interconfessional or interreligious theological associations or charitable bodies, as well as to participate in international theological events as speakers;

3. The Holy Synod sanctions that Romanian Orthodox theologians will obtain the blessing (approval) of the Patriarch of All Romania to participate in international theological events as speakers if they submit to the Department for Theological Educational of the Patriarchate Administration a written request, along with the written consent of their Bishop, their curriculum vitae and a description of the topic of the event and of the subject of the paper they will deliver" (originally Romanian).

\footnotetext{
${ }^{5}$ The Romanian Agency for Quality Assurance in Higher Education (ARACIS) is the public agency legally responsible with the evaluation, accreditation and temporary authorisation of higher education in Romania. ARACIS is a full member of the European Association for Quality Assurance in Higher Education (ENQA) and is recorded in the European 2uality Assurance Register for Higher Education (EQAR).

${ }^{6}$ It was not published in Monitorul Oficial al României ('The Official Gazette of Romania'), as is compulsory in the case of legal documents. This official periodical is controlled by the government and publishes acts provided by the Constitutions, laws, decisions, motions, decrees, emergency ordinances, normative acts and other documents mentioned by the law determining the structure and functioning of the Official Gazette.

${ }^{7}$ The Holy Synod is the supreme authority of the Romanian Orthodox Church for all dogmatic, canonical and clerical matters. It is presided by the Patriarch of All Romania. The Synod consists of all the metropolitans, archbishops, bishops and auxiliary bishops of the Romanian Orthodox Church (see Wikipedia for "The Holy Synod of the Romanian Orthodox Church", originally Romanian).
} 


\section{Text analysis}

The first paragraph could be considered unconstitutional. Despite the fact that the right to enter associations is stipulated in the Constitution of Romania (Art. 40 (1): "Citizens may freely become affiliated to political parties, unions, business owners' organisation and any other form of association.", originally Romanian [online]), the Holy Synod of the Romanian Orthodox Church restricts this freedom and conditions it on the hierarchical agreement of the ecclesiastic superior. In other words, a bishop may claim to be above current legislation, which may be deemed completely hilarious. Normally, a member of the university teaching staff, even one with theological education, should have the right to choose freely the organisations to which (s)he affiliates in agreement with his/her research interests and subjects (s)he teaches. Limiting the right to join associations of one's free will by demanding one to have the bishop's written consent is discriminating and it hinders the equality of opportunity of the members of the academic community. Obtaining the bishop's consent is not provided by any university charter and invoking such an act undermines university autonomy, but it can also affect the academic achievements of the teaching staff. The affiliation to certain scientific associations/organisations offers members benefits, such as free access to scientific data bases and exchanges of opinions with specialists all over the world. This results in professional advancement, personal development and, implicitly, the chance to spiritual progress.

The second interdiction in the first paragraph refers to the restriction to participate in international theological events as speakers. The written consent of the bishop and the blessing (approval) of the Patriarch of All Romania foregrounds the right to free movement, stipulated in Article 25 of the Constitution of Romania (originally Romanian): "The right to free movement in the country and abroad is guaranteed. The law establishes the prerequisites for exercising this right." [online]. Thus, although it is not a law (as it was not published in the Official Gazette), the Decision of the Holy Synod of the Romanian Orthodox Church, adopted in the working session of 24 May 2018 (Argument no. 4761/2018), is assumed with this quality and it is imposed as such for Orthodox theologians in the academic milieu.

The third implicit interdiction in the first paragraph undermines freedom of expression, which is also mentioned in the Constitution of Romania, in Article 30: "(1) The freedom to express thoughts, opinions or beliefs and to be creative in any way, in speech or in writing, through sounds or by any other means of public communication, cannot be violated. (2) Censorship is forbidden under every circumstance" (originally Romanian) [online]. The written agreement of the bishop and the blessing (approval) of the Patriarch of All Romania cannot be construed otherwise than as a cunning form of censorship, masked by the priests' canonical duty to be obedient to their hierarchical superiors. While this paragraph is religiously legitimate, as those ordained must listen to their superiors and obey them unconditionally, in the academic milieu the text conveys a subjective, discretionary and scientifically ungrounded constraint. According to the decision of the Synod of the Romanian Orthodox Church, the members of the teaching staff of a faculty of theology are assessed avant la lettre by a bishop who may not have advanced scientific and didactic training, nor pertain to an internationally renowned academic organisation ${ }^{8}$. Thus, the candidate will not be evaluated according to objective, scientific criteria, but subjectively, according to denominational-dogmatic principles. Contemporary academia should not have to deal with the bestowal of discretionary deciding authority upon bishops who often lack the necessary expertise in carrying out thorough, impartial evaluations and who do not have a proficient scientific committee to which to turn for support in blessing/rejecting a potential participant in an international scientific event. However, although one could argue that the bishop is advised by counsellors in decision-making, it should be noted that most such counsellors are chosen based on the principle of obedience to the bishop. Thus, the clerical

\footnotetext{
${ }^{8}$ Exceptions may exist, but they prove the rule. A favourable example is the Archbishop and Metropolitan Andrei Andreicuț, Professor at Babeș-Bolyai University of Cluj-Napoca and "1 December 1918” University of Alba Iulia, who is also a member of the European Academy of Science and Arts in Salzburg (Austria).
} 
quality of the individuals is more important than their intellectual skills. In other words, science is inferior to religiousness.

As underlined by Felecan \& Munteanu Siserman (2018, p. 178), "the intrusion of the Church in secular, state education is unacceptable, as the Church is not the main credit authority". As bishoprics do not cover participation expenses of members of university teaching staff for international scientific events (i.e., participation fee, travel costs, accommodation, per diem etc.), they should not have the moral right to restrict the participation altogether, especially since this is a personal option, related to researchers' intellectual, scientific abilities or their financial possibilities. This undermines the right of members of the teaching staff to choose the scientific events in which they can participate and to travel where these events are held, as beforehand they have to obey a potential veto of the bishop. International conferences/congresses have scientific committees consisting of highly competent figures in the field. They are based on the system of blind peer review, which ensures the objective selection of papers and participants implicitly. However, the Synod of the Romanian Orthodox Church confers more rights on a bishop without the need to mention whether he was co-opted or not in the scientific committee of the event for which his written agreement is required. Put differently, objectivity is annulled and subjectivism is imposed as the preliminary criterion for any international scientific enterprise.

On the other hand, the choice of researchers who wish to participate in international scientific events, as decided by the Synod of the Romanian Orthodox Church, opposes the internal regulation of the Church to university autonomy. This attitude can be illustrated by quoting a passage of a university charter: "The university is a space free from political, religious or economic obtrusions, pressures or constraints, with the exception of scientific, legal and ethical constraints. The University staff is protected against censorship, manipulation and oppression, while being obliged to meet scientific standards and professional duties. Members of the academic community must avoid injuring others' freedom in agreement with the principle of respecting differences" (p. 40, originally Romanian, author's italics).

One could object that priests have to obey their superiors, namely the bishops that ordained them (or not), which is common behaviour among the clergy?. The problem is that, according to the way in which the synodal document is phrased, the decision does not refer to priests, but to Romanian Orthodox theologians. Nevertheless, there exist theologians who are not priests and only carry out scientific activity in universities. Thus, a constraint like that found in the text analysed is restrictive and absurd. Academic liberty is disregarded and theologians are mistaken for ordained individuals. Internal regulations of the Church should not be applicable/valid in universities, as the Church is a conservative institution, attached to dogmas dating to almost two millennia ago, whereas universities are promoters of progress and innovation. Restricting the freedom of expression by restraining the right to participate in scientific events is not only illegal and in opposition with university charters in civilised, democratic states, but also immoral, unethical.

In the twenty-first century the Romanian Orthodox Church imposes such constraints on Romanian Orthodox theologians, although the academia did not accept these restrictions in the Middle Ages either. Is it that the Romanian Orthodox Church does not trust its theologians or does it simply wish to have absolute control over hierarchically inferior members of the clergy? A fair enterprise would have been to adopt a decision about partially subsidising participations in international scientific events, so as a great number of Romanian theologians could gain access to disseminating ideas in the scientific world. The attitude of the Romanian Orthodox Church is not only unethical, but it also subverts the essence of the academic spirit: "Officially, the central business of universities is the creation and communication of knowledge, which can be called public knowledge" (Ziman, 1968 apud Martin, 2017, p. 11). The substance of a teacher's mission was pointed out by Bertrand Russel in the mid-twentieth century: "The teacher, like the artist, the philosopher, and the man of letters, can only perform his work adequately if

${ }^{9}$ As in the case of the army, the virtue of obedience is also invoked within the Church, with reference to hierarchical superiors (who are considered infallible) rather than to the dogmatic and moral integrity of the Church [online]. 
he feels himself to be an individual directed by an inner creative impulse, not dominated and fettered by an outside authority" (Russell, 1950, p. 159). Like the teacher, the researcher has a liberal calling and his/her role in society is to disseminate the results of his/her work by means of scientific publications and presentations on the occasion of various scientific events. To this end, researchers should be supported to gain access to the latest achievements in their line of work; they should not be restrained arbitrarily by hierarchical superiors. Just as a doctoral supervisor is meant "to support the student in developing capacities, for example for collecting information, analysing data, formulating hypotheses and writing up findings, depending on the discipline" (Martin, 2017, p. 12), a bishop or the Patriarch of All Romania should encourage theologian-researchers to disseminate their ideas unconstrainedly in the international scientific world. The participation in an international conference is the visible manifestation of research performance.

The decision of the Synod of the Romanian Orthodox Church to have complete power over the quality of its "subordinates" to be members of Orthodox, interconfessional or interreligious theological associations or charitable bodies or to participate in international theological events as speakers is not only a form of censorship, but it is also indicative of the Church's distrust of its elite teaching staff, who should be allowed to reach beyond national, religiously restrictive confines and interact with theologians from other countries and cultures, pertaining to various faiths and religions. The lack of trust is manifested a priori, lest the image of the Romanian Orthodox Church, in particular, and that of the Orthodox faith, in general, be affected. Nonetheless, according to Corlett, "those who seek to curtail higher educational academic freedom rights by way of censorship stand on unreasonable ethical grounds to do so (...). Offensiphobia ought to be rejected as it is unsupported by the balance of reason" (Corlett, 2018, p. 113). If restricting theologians' free access to international scientific events may be construed as excessive cautiousness on the side of the Church, in the academic environment it is a violation of freedom, an interference with researchers' achievements and international visibility, a limitation of the unrestrained exchange of information. Universities must be granted the right to govern their internal affairs (regarding teaching, research and management) in practice and in terms of policies. The research abilities of a professor of theology should be quantified according to scientific criteria rather than religious ones. Internal regulations of the Church should not be allowed to obtrude upon the academic milieu or to become valid in this context, as they would undermine academic freedom, in particular, and freedom of expression, in general. Individual freedom is tightly linked to academic liberty ${ }^{10}$. The continual intrusion of the Romanian Orthodox Church into universities may be interpreted as an incessant attack on university autonomy, as a wish to subdue and control the academic milieu, under the pretext of managing theological matters. Being aware of the power and influence of the Romanian Orthodox Church in deeply traditional Romanian society, no university dares challenge the Church or establish a boundary that the Church could not cross without infringing on university autonomy. Due to its dominant position in Romania and by means of power abuse, the Romanian Orthodox Church intimidates the academic environment, in general, and theologians, in particular, thereby ensuring its ongoing supremacy and the impossibility of certain theologians' criticism to be disseminated abroad or at least to reach the international scientific world.

\section{Conclusions}

The decision of the Synod of the Romanian Orthodox Church is controversial, as it undermines academic freedom. According to Corlett's analysis in Offensiphobia (2018, p. 120), one can point out the subversion of "at least three general categories: rights to freedom of expression in research, rights to freedom of expression in teaching, and rights to freedom of expression in service". Human rights are violated (freedom of association, movement and expression), in correlation with rights of academic researchers: "There is also the right to freely attempt to publish on which topics and in which journals and on which

\footnotetext{
${ }^{10}$ Corlett (2018) considers that "academic freedom is a species of freedom of expression" (p. 144).
} 
presses one chooses" (Corlett, 2018, p. 120). The attempt of the Church to eliminate theological errors or potential criticism about it is a kind of censorship that cannot be tolerated in the twenty-first-century academic world. It is a moral issue, and the homogenisation of Romanian theologians' thinking is not only unethical, but also counterproductive and humiliating. The so-called "preliminary peer review" of a bishop accounts for the use of censorship at the heart of the Church. The gradual restraint of liberties, not met with protest by the Romanian academia, may lead to the proliferation of such undemocratic decisions and the consolidation of the role of the Church as the institution pulling the strings in Romanian society. The dominant power abuse allows the Romanian Orthodox Church to disregard current laws and adopt decisions that subvert personal and academic freedom alike. The lack of response from the Romanian society, in general, and the academic milieu, in particular, is suggestive of silent complicity. Unfortunately, individuals who opposed these measures were subject to punishment: they lost the courses they taught at theological bachelor programmes, they were not allowed to obtain a promotion or legal rewards (e.g., merit pay) or they were harassed with the purpose of being persuaded to give up their "fight" or to be inculcated with the idea that any enterprise they might venture to carry out would render them similar to Don Quixote.

It is ill-advised to be discouraged/display a defensive attitude and accept such decisions. We have the moral duty to point out the unacceptable effects that certain decisions of the Romanian Orthodox Church have on the Romanian academic environment and scientific research.

\section{Bibliography}

\section{A. References}

Corlett, J.A. (2018). Offensiphobia, in “The Journal of Ethics”, 22 (2), p. 113-146, Crossref.

Felecan, O. \& Munteanu Siserman, M. (2018). Interpretări sociolingvistice ale unui text administrativ emis de instituții bisericești, in "Text și discurs religios", 9, p. 173-184.

Martin, B. (2017). Defending university integrity, in "International Journal for Educational Integrity”, 13 (1), Crossref.

Russell, B. (1950). Unpopular Essays, Simon \& Schuster, New York.

Ziman, J. (1968). Public knowledge: an essay concerning the social dimension of science, Cambridge University Press, Cambridge.

\section{B. Web pages (accessed in July 2018)}

Agenția Română de Asigurare a Calității în Învăţămîntul Superior [Romanian Agency for Quality Assurance in Higher Education] (ARACIS) [online].

Constituția României [Constitution of Romania] [online].

The Constitutional Court of Romania (CCR) [online].

Cuvîntul Ortodox [The Orthodox Word] (2018). Ascultarea, pretextele și abuzurile ei - părintele Savatie pune punctul pe I [Obedience, pretexts and abuses - Father Savatie dots the i's and crosses the t's] [online].

European Association for Quality Assurance in Higher Education (ENQA) [online].

European Quality Assurance Register for Higher Education (EQAR) [online].

Institutul Național de Statistică România [Romanian National Institute of Statistics] (2013). Ce ne spune recensămîntul din anul 2011 despre religie [What does the 2011 census tell us about religion?] [online].

Petitieonline.com (2014). Impozitarea veniturilor Bisericii Ortodoxe Române [Imposing a tax on the income of the Romanian Orthodox Church] [online].

Schmitt, O.J. (2018). Ob Faschisten oder Kommunisten - Rumäniens orthodoxe Kirche war stets eine Dienerin der Macht, în „Neue Zürcher Zeitung” [online].

WIN-Gallup International (2012). Global Index of Religion and Atheism [online]. 